\title{
Photodynamic therapy in actinic cheilitis: clinical and anatomopathological evaluation of 19 patients ${ }^{*}$
}

\author{
Tratamento de queilite actínica com terapia fotodinâmica - avaliação clínica e \\ anatomopatológica de 19 pacientes
}

\author{
Camila Ferrari Ribeiro ${ }^{1}$ \\ Juliana Merheb Jordão ${ }^{3}$ \\ Lismary Mesquita ${ }^{5}$ \\ Luciana Lisboa Faucz ${ }^{7}$
}

\author{
Fernanda Homem de Mello de Souza ${ }^{2}$ \\ Letícia Cortes Haendchen ${ }^{4}$ \\ Juliano Vilaverde Schmitt ${ }^{6}$
}

\begin{abstract}
BACKGROUND: Actinic cheilitis, a common disease caused by chronic solar exposure and tobacco use, is considered a premalignant lesion with potential to develop into squamous cell carcinoma. Some of the available treatments are invasive, have unaesthetic results and require multiple sessions.

OBJECTIVE: To assess the efficacy of a therapy and its cosmetic results.

METHODS: In this uncontrolled clinical trial a single photodynamic therapy (PDT) session using $16 \%$ methyl-aminolevulinate was performed on actinic cheilitis of the lower lip. A standardized questionnaire was applied in order to assess the clinical improvement from the patients' point of view and the satisfaction with the treatment. Anatomopathological evaluation was performed before the treatment and two months afterwards.

RESULTS: The sample was composed of 19 patients (10 males and 9 females), phototypes I to III, with average age of 62 years. Main adverse effects were: sudden pain, scabs, herpes flare-up, and edema. The average score of pain during the procedure was $5,8+2,9$. At the final assessment the patients reported improvement of $80 \%$ and satisfaction of $85 \%(p<0.01)$. Anatomopathological analysis showed a significant decrease of dysplasia $(p=0.03)$ in spite of its presence in $84 \%$ of cases. There was no significant correlation between the level of dysplasia with either the subjective impression of clinical improvement $(\mathrm{p}=0.82)$ or with the patients' final satisfaction $(\mathrm{p}=0.96)$.

ConcLusion: PDT is effective in the treatment of actinic cheilitis, but it is associated with a significant level of pain. Due to the persistence of dysplasia, more research needs to be done in order to define the ideal number of sessions for the effective treatment of these lesions.
\end{abstract}

Keywords: Carcinoma, squamous cell; Cheilitis; Pathology; Patient satisfaction; Photochemotherapy

Resumo: FunDAMENTOS: Queilite actínica, afecção causada por exposição solar crônica e tabagismo, é considerada lesão pré-maligna com possibilidade de transformação para carcinoma espinocelular. Alguns tratamentos descritos são invasivos, têm resultados inestéticos e requerem múltiplas aplicações.

OвJETIVO: Verificar o uso de tratamento efetivo com resultado esteticamente aceitável.

MÉTODOS: Ensaio clínico não controlado, utilizando terapia fotodinâmica com cloridrato de aminolevulinato de metila creme 16\%, única aplicação, na queilite actínica de lábio inferior. Aplicação de questionário padronizado para avaliar melhora clínica da lesão subjetiva do paciente e satisfação com tratamento. Avaliação anatomopatológica antes da aplicação e dois meses após.

RESULTADOS: Amostra compreendeu 19 pacientes (10 homens e 9 mulheres), fototipos I a III, idade média 62 anos. Principais efeitos adversos: dor imediata, crostas, herpes labial e edema. Escore médio de dor referida durante o procedimento foi 5,8 $\pm 2,9$. Na avaliação final, os pacientes referiram melhora de $80 \%$ das lesões e apresentaram mediana de $85 \%$ de satisfação $(\mathrm{p}<0,01)$. Análise anatomopatológica mostrou diminuição significativa de displasia $(\mathrm{p}=0,03)$, apesar da persistência em $84 \%$ dos casos. Não houve correlação significativa da redução no grau de displasia com impressão subjetiva de melhora clínica $(p=0,82)$ ou com satisfação final do paciente $(\mathrm{p}=0,96)$.

ConcLusẫ: TFD é efetiva no tratamento da queilite actínica, porém associada a grau significativo de dor. Devido à persistência de displasia, mais estudos são necessários para definir o número ideal de aplicações para tratamento efetivo destas lesões.

Palavras-chave: Carcinoma de células escamosas; Fotoquimioterapia; Patologia; Queilite; Satisfação do paciente

Received on 30.03.2011.

Approved by the Advisory Board and accepted for publication on 16.05.2011.

* Work performed at the Dermatology Outpatients Clinic of the Hospital Universitário Evangélico de Curitiba - Faculdade Evangélica do Paraná (FEPAR-HUEC)

- Curitiba (PR), Brazil.

Financial Support: None.

Conflict of Interests: None.

Dermatology Trainee at the Hospital Universitário Evangélico de Curitiba - Faculdade Evangélica do Paraná (FEPAR-HUEC) - Curitiba (PR), Brazil.

Dermatologist - Hospital Universitário Evangélico de Curitiba - Faculdade Evangélica do Paraná (FEPAR-HUEC) - Curitiba (PR), Brazil.

Dermatologist - Private Clinic - Curitiba (PR), Brazil.

Dermatologist - São Paulo (SP), Brazil.

Pathologist, specialist in Dermatopathology. - Dermatopathologist of the Irmandade da Santa Casa de Misericórdia de Curitiba - Curitiba (PR), Brazil.

Dermatologist - Preceptor at the Dermatology Service of the Hospital Universitário Evangélico de Curitiba - Faculdade Evangélica do Paraná (FEPAR-HUEC) Curitiba (PR), Brazil.

PhD in Sciences by the Universidade de São Paulo (USP) - Preceptor at the Dermatology Service of the Hospital Universitário Evangélico de Curitiba Faculdade Evangélica do Paraná (FEPAR-HUEC) - Curitiba (PR), Brazil. 


\section{INTRODUCTION}

Actinic cheilitis is a common condition, mostly located on the lower lip, resulting from chronic solar exposure. It is also associated with smoking. ${ }^{1}$ As with other actinic skin keratoses, it is considered a premalignant lesion which could develop into squamous cell carcinoma (SCC). ${ }^{2}$ Markopoulos, AlbanidouFarmaki and Kayavis reported a development into SCC of $16.9 \%$ of 65 cases of actinic cheilitis. ${ }^{1}$ It is known that the risk of metastasis from SCC in the lip is 4 times higher that from cutaneous SCC. ${ }^{1,3}$

Actinic cheilitis is characterized by erythema and edema, progressing with atrophy, hyperkeratosis and erosions or ulcerations. The main histological criteria are atypia and the loss of polarity of the keratinocytes of the lower portion of the epithelium, associated with solar elastosis and inflammatory infiltrate. The atypias can be classified as mild, moderate or severe, according to the cellular alterations found. ${ }^{4}$ Histological subtypes of actinic cheilitis are also described, taking into consideration findings like hyperkeratosis, atrophy, acantholysis and lichenoid pattern of the inflammatory infiltrate.

There is some difficulty in using the usual therapies for actinic keratoses in the lip, with lower cure rates. The main treatments are the vermillionectomy, $\mathrm{CO} 2$ or Erbium laser ablation and electro-dissection. These treatments are invasive, require local or general anesthesia, and offer risk of unaesthetic scars as well. ${ }^{5-7}$ Other therapeutic modalities used are topical cryotherapy, retinoid, 5\% fluorouracil (5-FU), Imiquimod, diclofenac and chemical peels. ${ }^{8-11}$ Treatments with 5-FU or Imiquimod take a long time, with important inflammatory reaction, and the collaboration of the patient is necessary. High recurrence rates of the lesions are observed with chemical peels. Cryotherapy may result in blisters formation, important pain and movement restriction in the treated area. Some studies, with a small number of patients, demonstrated a good clinical and histopathological response with the use of photodynamic therapy with 5-aminolevulinic acid and its methylate esther in the treatment of actinic cheilitis. ${ }^{2,12-14}$

The topical photodynamic therapy (PDT) in the treatment of non-melanoma skin cancer was described in 1990 by Kennedy, Pottier and Pross. ${ }^{15}$ Nowadays it is widely used in the treatment of actinic keratoses and superficial non-melanoma skin neoplasias. ${ }^{16}$ The high efficacy of PDT in the treatment of actinic cheilitis was reported in various studies, with cure rates between 70 and $90 \%$, with good cosmetic results and a high level of patient satisfaction. ${ }^{17,18}$ PDT, performed with a combination of 5-aminolevulinic acid (5-ALA) and blue light was approved by the FDA for the treatment of actinic keratoses in 1999. This therapeutic modality is based on the use of a tissue photosensitizer, applied topically or systemically, and subsequent irradiation with laser light or light bulb (visible light between 400 and $700 \mathrm{~nm}$ ), inducing cell death by generating oxygen reactive species. ${ }^{19}$ In most studies 5-ALA was used in cream or gel, in concentrations from 3 to $20 \%$. The addition of dimethyl sulfoxide increases the penetration of the 5-ALA. The methylate esther of 5-ALA, methyl aminolevulinate (MAL) or methylaminomethylaminopentanoate (MAOP), was subsequently developed for use in PDT. The MAL shows a higher specificity for the neoplastic cells and its use with red light was approved in 2003 for the treatment of actinic keratoses in Germany. ${ }^{18,20}$

The objective of this study was to assess the efficacy and applicability of PDT in the treatment of actinic cheilitis, with clinical and anatomopathological analyses, as well as analyses of the collateral effects and clinical improvement assessed by the patient, since less invasive approaches have been used more often in the treatment of this disorder.

\section{MATERIAL AND METHODS}

This was an experimental, non controlled clinical trial. Nineteen patients from spontaneous demand of the general dermatology outpatients' clinic seen between April and June 2009 were selected based on a clinical and anatomopathologic diagnosis of actinic cheilitis. Patients with idiopathic immunosuppression or immunosupression due to a specific disease or to therapeutic reasons; porphyria; known allergy to MAL or to a similar photosensitizing agent or excipient; known hypersensitivity to nut products or to other protein antigens; pregnancy; lactation; inadequate contraception during treatment and for 1 month afterwards in fertile age women; any condition which might compromise the collaboration of the patient with the study; regular UV treatment or treatment of the lower lip with local therapy (including cryotherapy and curettage) in the last 30 days or topical treatment (including imiquimod, 5\% fluorouracil and diclofenac) in the last 3 months were excluded. All patients signed the free and informed consent form and the project was approved by the local Ethics Committee.

The size of the sample was defined base $\underset{12,13,14}{d}$ similar studies from indexed scientific literature.

Before the treatment the patients had a $3.0 \mathrm{~mm}$ punch biopsy a clinically most affected area of the lower lip. Afterwards, a suture with 6.0 mononylon suture was performed and the stitches were removed in 7 days.

The patients were recruited and 16\% methyl aminolevulinate hydrochloride cream was applied once to the lower lip and to a $5 \mathrm{~mm}$ strip of adjacent 
skin, in a dark room. Crusts and scabs which might disturb the treatment were carefully removed. A cotton roll was used on the internal part of the lower lip for better exposure of the area to be treated; the area was covered with plastic film and subsequently a Black-out tissue secured with micropore. Three hours after the application the protection was removed. Then the patients were exposed to a source of red light (LED) with an emission peak of $630 \mathrm{~nm}, 37 \mathrm{~J} / \mathrm{cm}^{2}$ fluency, $71 \mathrm{mw} / \mathrm{cm}^{2}$ potency (irradiancy) for a period of $8 \mathrm{~min}$ utes and 40 seconds, at a distance of 5 to $7 \mathrm{~cm}$.

The patients were assessed immediately after the procedure, after 7 days and after a period that varied from 51 to 94 days (average of 62.5 days), when a biopsy after the procedure was taken (within the same standards as the biopsy before the procedure). The biopsy area chosen was based on the area with the highest clinical severity.

A standardized questionnaire applied to the patients assessed the subjective impression of each of them in terms of pain, improvement of the lesion, satisfaction with the treatment and eventual complaints. In order to evaluate the pain an analogical scale, varying from grade 0 (absence of pain) to grade 10 (most severe pain) was used. The improvement of the lesion was graded in percentages of $0 \%$ (absence of improvement) to $100 \%$ (complete improvement of the lesion). The level of satisfaction was also quantified in percentages of $0 \%$ (no satisfaction) to $100 \%$ (high satisfaction with the treatment).

The pre and post treatment lip biopsies were analyzed by an experienced dermatopathologist. The anatomopathological criteria observed was the level of epidermal dysplasia classified as discrete, moderate and severe.

Categorical variables were represented by percentages and analyzed by the chi-square or the Fisher's exact tests. The continuous variables had the normality of their distributions verified by the Shapiro-Wilk test and compared by the Student $T$ and Wilcoxon tests. They were represented by averages and standard deviations or medians and interquartile deviations, according to the distribution. The correlations were analyzed by the non-parametric Spearman test. The multivariate analysis of the characteristics related to the patient final satisfaction (dependable variable) was performed by the co-variance analysis (ANCOVA) with the following independent variables: age, score of immediate pain and impression of clinical improvement after 60 days. P-values lower than 0,05 were considered significant.

\section{RESULTS}

Nineteen patients were included, 53\% (10/19) men and $47 \%(9 / 19)$ women. The age varied from 35 to 78 years, with an average of $62 \pm 11$ years. The patient's phototypes varied from I to III on the Fitzpatrick classification. The complications observed after the procedure were, in decreasing order of frequency, immediate pain, crusts, herpes labialis, edema, scaling, erythema, itch and paresthesia.

The average score of pain referred during the procedure was $5,8 \pm 2,9($ median $=5)$, while between the $1^{\text {st }}$ and $7^{\text {th }}$ day it was practically absent, with a median of 0 ( $p<0,01$ - Wilcoxon). The median of the subjective impression of clinical improvement of the lesions by the patients, on the $7^{\text {th }}$ day was de $50 \pm 70$, increasing significantly to $80 \pm 402$ months after the application ( $p<0,01$ - Wilcoxon). The patients' final satisfaction after 60 days had a median of $80 \pm 40$. According to the multivariate analysis by ANCOVA this satisfaction correlated directly with the level of clinical improvement of the lesion and inversely with the age of the patient, and it was not significantly influenced by the pain score attributed to the procedure (Table 1). Actinic cheilitis lesions before and at 2 months after treatment with photodynamic therapy are illustrated in the figures 1 and 2 .

As for the anatomopathological analysis, from the 19 initial biopsies 18 had the common variant of actinic cheilitis and 1 the lichenoid variant. The level of pre-treatment dysplasia was discrete in 17 lesions and moderate in 2 , and there was a significant decrease on the level of dysplasia after treatment ( $p=0,03-$ Chi-square tendency), however $84 \%$ of the cases still had some level of dysplasia (Figure 3)

There was no significant correlation between the level of dysplasia and the subjective impression of clinical improvement ( $p=0,82$ - Spearman) or with the final patients' satisfaction ( $p=0,96$ - Spearman).

TABLE 1: Multivariate analysis of the characteristics related to the patients in relation to the final level of satisfaction"

\begin{tabular}{lllll} 
Variable & Coefficient & $95 \%$ & CI & p \\
\hline Age & $-0,72$ & $-1,08$ & $-0,36$ & $<0,01$ \\
$\begin{array}{l}\text { Immediate } \\
\text { pain score }\end{array}$ & 0,99 & $-0,45$ & 2,42 & 0,18 \\
$\begin{array}{l}\text { Impression of } \\
\text { clinical }\end{array}$ & 0,82 & 0,70 & 0,95 & $<0,01$ \\
$\begin{array}{l}\text { improvement } \\
\text { after } 60 \text { days }\end{array}$ & & & & \\
$\begin{array}{l}\text { Intercept } \\
\text { * Dependent variable: level of satisfaction after } 60 \text { days; } \\
\text { p (of the model) }<0,01\end{array}$ & &
\end{tabular}



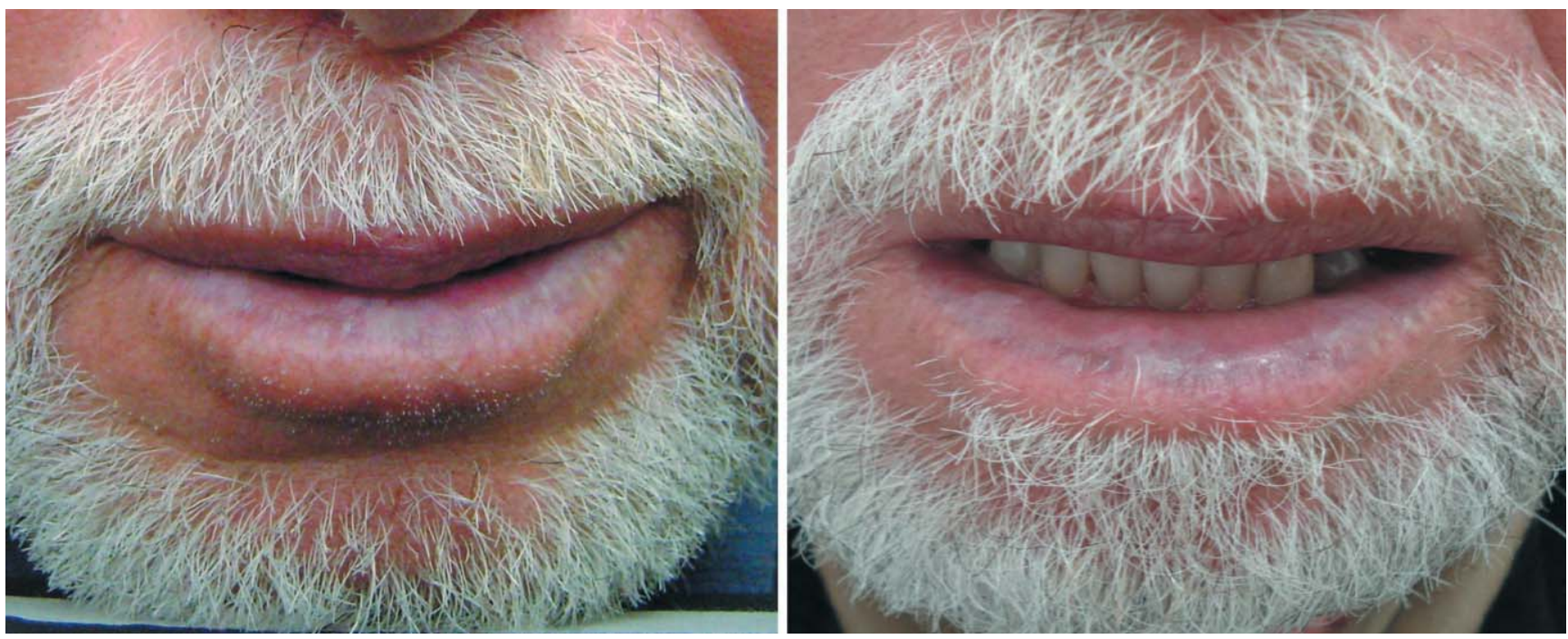

Figure 1: Actinic cheilitis in the lower lip. Before (left) and after (right) 2 months of PDT application
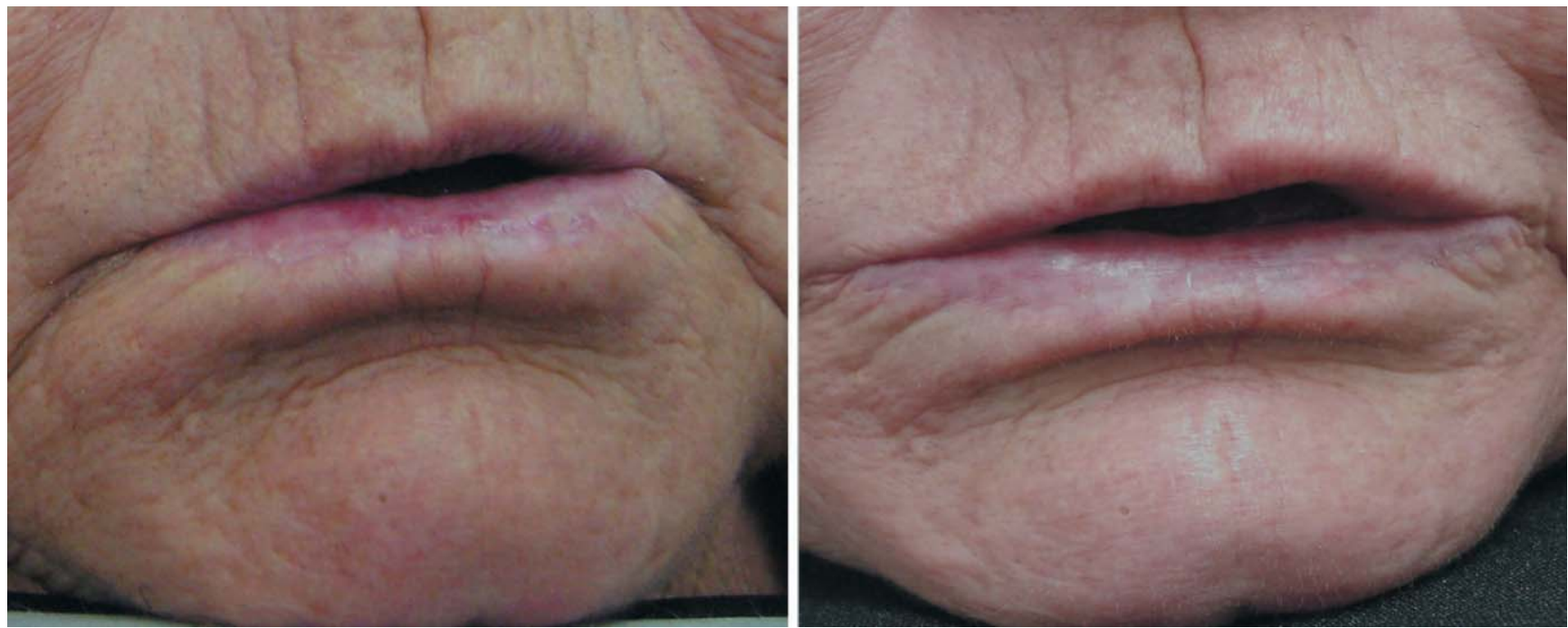

FIGURE 2: Actinic cheilitis in the lower lip. Before (left) and after (right) 2 months of PDT application

\section{DISCUSSION}

Photodynamic therapy is a non-invasive treatment, causes no bleeding, treats large areas with single application and has good cosmetic results. Because of these advantages it is considered an important therapeutic option in actinic keratoses and its use has increased considerably in the treatment of Bowen's disease, superficial basal cell carcinoma and actinic cheilitis. ${ }^{12-22}$

In the present study, the collateral effects presented by the patients were comparable with the ones already described in the literature. Berkin, Herzinger, Flaig, Brenner, Borelli and Degitz ${ }^{12}$ performed two applications of PDT (one week apart) in the lower lip of 15 patients, with ages and phototypes similar to the ones in our study, and also observed pain, crusts for- mation, edema and herpes flare-up as the more common complaints from the patients.

Pain is one of the main adverse effects of PDT. A retrospective study performed by Gholam et al, compared the pain from PDT in various cosmetic units (dorsum of the hands, lips, and malar, frontal and occipital regions). ${ }^{23}$ The authors concluded that the intensity of the pain was higher in the lips and decreased significantly 8 hours after the application. In the present study moderate pain was reported by the patients, with significant decrease after treatment, which indicates that the pain was short lived.

The clinical improvement of actinic cheilitis was analyzed in a study in which 19 patients were subjected to 1,2 or 3 sessions of PDT. ${ }^{21}$ In the groups of 

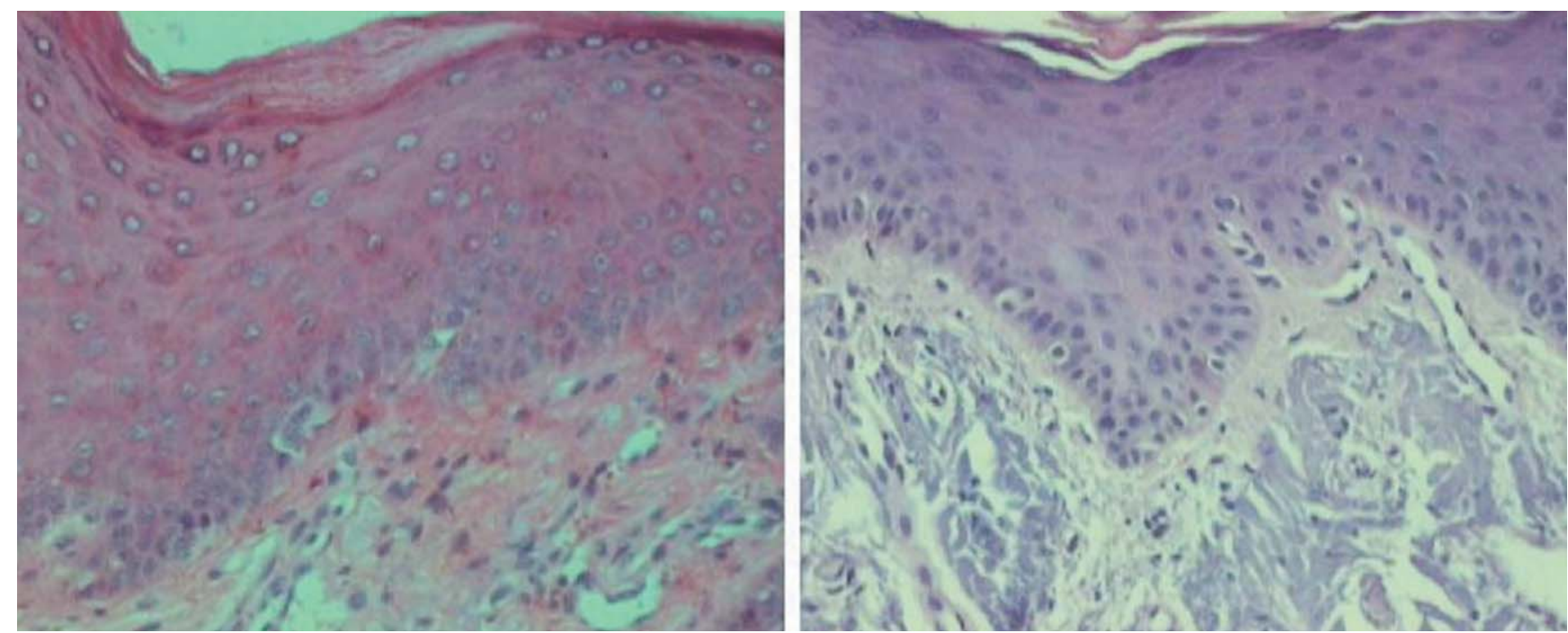

FIGURE 3: Left - anatomopathological exam before the performance of PDT; actinic cheilitis, common variant, discrete level of dysplasia and discrete inflammatory infiltrate, lymphocytic type. Right - anatomopathological exam 2 months after application of PDT; absence of dysplasia and absence of inflammatory infiltrate. HE, aumento $100 \mathrm{x}$

patients subjected to 1 or 2 applications a complete clinical improvement was seen in $47 \%$ of the cases and in the group subjected to 3 sessions, in $68 \%$. No histopathological evaluations were performed. The level of improvement by the patients' assessment in our study was higher 2 months after the treatment than after 1 week, which indicates that the improvement was better perceived in the long run. We also assessed the patients' satisfaction with the treatment, which had a high median (85\%) after 2 months and correlated with the improvement perceived by the patients. However, there was an inverse correlation between satisfaction and age, which indicates that younger individuals can better tolerate the application. Patient satisfaction was not significantly influenced by the pain attributed to the procedure.
As for the histopathological analysis, we observed persistence of the dysplasia after treatment in 13 patients (84\%), however, there was a significant reduction of its intensity. One of the limitations of our study was the application of only one session of PDT. On the other hand, the study by Berkin, Herzinger, Flaig, Brenner, Borelli and Degitz ${ }^{12}$ demonstrated that after two applications of PDT, $62 \%$ of the patients still had dysplasia. We believe that more studies are necessary in order to define the ideal number of applications for the effective treatment of these lesions.

\section{CONCLUSION}

We concluded that photodynamic therapy is an effective tool in the treatment of actinic cheilitis, however it is frequently associated with a significant level of pain. Despite the presence of moderate pain, patient satisfaction was not compromised. 


\section{REFERENCES}

1. Markopoulos A, Albanidou-Farmaki E, Kayavis I. Actinic cheilitis: clinical and pathologic characteristics in 65 cases. Oral Dis. 2004;10:212-6.

2. Kodama M, Watanabe D, Akita Y, Tamada Y, Matsumoto Y. Photodynamic therapy for the treatment of actinic cheilitis. Photodermatol Photoimmunol Photomed. 2007;23:209-10.

3. Nico MMS, Rivitti EA, Lourenco SV. Actinic cheilitis: histologic study of the entire vermilion and comparison with previous biopsy. J Cutan Pathol. 2007;34:309-14.

4. Cavalcante AS, Anbinder AL, Carvalho YR. Actinic cheilitis: clinical and histological features. J Oral Maxillofac Surg. 2008;66:498-503.

5. Dufresne RG Jr, Garrett $A B$, Bailin PL, Ratz JL. Carbon dioxide laser treatment of chronic actinic cheilitis. J Am Acad Dermatol. 1988;19:876-8.

6. Laws RA. Comparison of electrodessication with $\mathrm{CO} 2$ laser for the treatment of actinic cheilitis. Dermatol Surg. 2000;26:349-53.

7. Zelickson BD, Roenigk RK. Actinic cheilitis: treatment with the carbon dioxide laser. Cancer. 1990;65:1307-11.

8. Epstein E. Treatment of lip keratoses (actinic cheilitis) with topical fluorouracil. Arch Dermatol. 1977;113:906-8.

9. Robinson JK. Actinic cheilitis: a prospective study comparing four treatment methods. Arch Otolaryngol Head Neck Surg. 1989;115:848-52.

10. Smith KJ, Germain M, Yeager J, Skelton $\mathrm{H}$. Topical $5 \%$ imiquimod for the therapy of actinic cheilitis. J Am Acad Dermatol. 2002;47:497-501.

11. Ulrich C, Forschner T, Ulrich M, Stockfleth E, Sterry W, Termeer C. Management of actinic cheilitis using diclofenac $3 \%$ gel: a report of six cases. $\mathrm{Br} \mathrm{J}$ Dermatol. 2007; 156:43-6

12. Berking $\mathrm{C}$, Herzinger T, Flaig MJ, Brenner M, Borelli C, Degitz K. The efficacy of photodynamic therapy in actinic cheilitis of the lower lip: a prospective study of 15 patients. Dermatol Surg. 2007;33:825-30.

13. Hauschild A, Lischner S, Lange-Asschenfeldt B, Egberts F. Treatment of actinic cheilitis using photodynamic therapy with methyl aminolevulinate: report of three cases. Dermatol Surg. 2005;31:1344-7.

14. Stender IM, Wulf HC. Photodynamic therapy with 5 -aminolevulinic acid in the treatment of actinic cheilitis. Br J Dermatol. 1996;135:454-6.

15. Kennedy JC, Pottier RH, Pross DC. Photodynamic therapy with endogenous protoporphyrin IX. Basic principles and present clinical experience. J Photochem Photobiol B. $1990: 6: 143-8$.
16. Jeffes EW, McCullough JL, Weinstein GD, Fergin PE, Nelson JS, Shull TF, et al. Photodynamic therapy of actinic keratosis with topical 5-aminolevulinic acid: a pilot dose-ranging study. Arch Dermatol. 1997;133:727-32.

17. Morton $\mathrm{CA}$, Brown $\mathrm{SB}$, Collins $\mathrm{S}$, Ibbotson $\mathrm{S}$, Jenkinson $\mathrm{H}$, Kurwa $\mathrm{H}$, et al. Guidelines for topical photodynamic therapy: report of a workshop of the British Photodermatology Group. Br J Dermatol. 2002;146:552-67.

18. Szeimies RM, Karrer S, Radakovic-Fijan S, Tanew A, Calzavara-Pinton PG, Zane C, et al. Photodynamic therapy using topical methyl 5 -aminolevulinate compared with cryotherapy for actinic keratosis: a prospective, randomized study. J Am Acad Dermatol. 2002;47:258-62.

19. Karrer S, Szeimies RM, Hohenleutner U, Landthaler M. Role of lasers and photodynamic therapy in the treatment of cutaneous malignancy. Am J Clin Dermatol. 2001;2:229-37.

20. Pariser DM, Lowe NJ, Stewart DM, Jarratt MT, Lucky AW, Pariser RJ, et al. Photodynamic therapy with topical methyl aminolevulinate for actinic keratosis: results of a prospective randomized multicenter trial. J Am Acad Dermatol. 2003;48:227-32.

21. Alexiades-Armenakas MR, Geronemus RG. Laser-mediated photodynamic therapy of actinic cheilitis. J Drugs Dermatol. 2004;3:548-51.

22. Torezan L, Niwa ABM, Festa Neto C. Terapia fotodinamica em dermatologia: princípios básicos e aplicações. An Bras Dermatol. 2009;84:445-59.

23. Gholam P, Denk K, Sehr T, Enk A, Hartmann M. Factors influencing pain intensity during topical photodynamic therapy of complete cosmetic units for actinic keratosis. J Am Acad Dermatol. 2010;63:213-8.

MAILING ADDRESS:
Camila Ferrari Ribeiro
Serviço de Dermatologia - Centro Médico do
Hospital Evangélico
Av Sete de Setembro, 4713, $2^{\circ}$ Andar. Batel
80240 OOO Curitiba PR
E-mail: ferrarimed@yaboo.com.br

How to cite this article: Ribeiro CF, Souza FHM, Jordão JM, Haendchen LC, Mesquita L, Schmitt JV, Faucz LL. Photodynamic therapy in actinic cheilitis: clinical and anatomopathological evaluation of 19 patients. An Bras Dermatol. 2012;87(3):418-23. 